\title{
Environmental assessment of garden waste management in the Municipality of Aarhus, Denmark
}

Boldrin, Alessio; Andersen, Jacob Kragh; Christensen, Thomas Højlund

Published in:

Waste Management

Link to article, DOI:

10.1016/j.wasman.2011.01.010

Publication date:

2011

Link back to DTU Orbit

Citation (APA):

Boldrin, A., Andersen, J. K., \& Christensen, T. H. (2011). Environmental assessment of garden waste management in the Municipality of Aarhus, Denmark. Waste Management, 31(7), 1560-1569.

https://doi.org/10.1016/j.wasman.2011.01.010

\section{General rights}

Copyright and moral rights for the publications made accessible in the public portal are retained by the authors and/or other copyright owners and it is a condition of accessing publications that users recognise and abide by the legal requirements associated with these rights.

- Users may download and print one copy of any publication from the public portal for the purpose of private study or research.

- You may not further distribute the material or use it for any profit-making activity or commercial gain

- You may freely distribute the URL identifying the publication in the public portal

If you believe that this document breaches copyright please contact us providing details, and we will remove access to the work immediately and investigate your claim. 


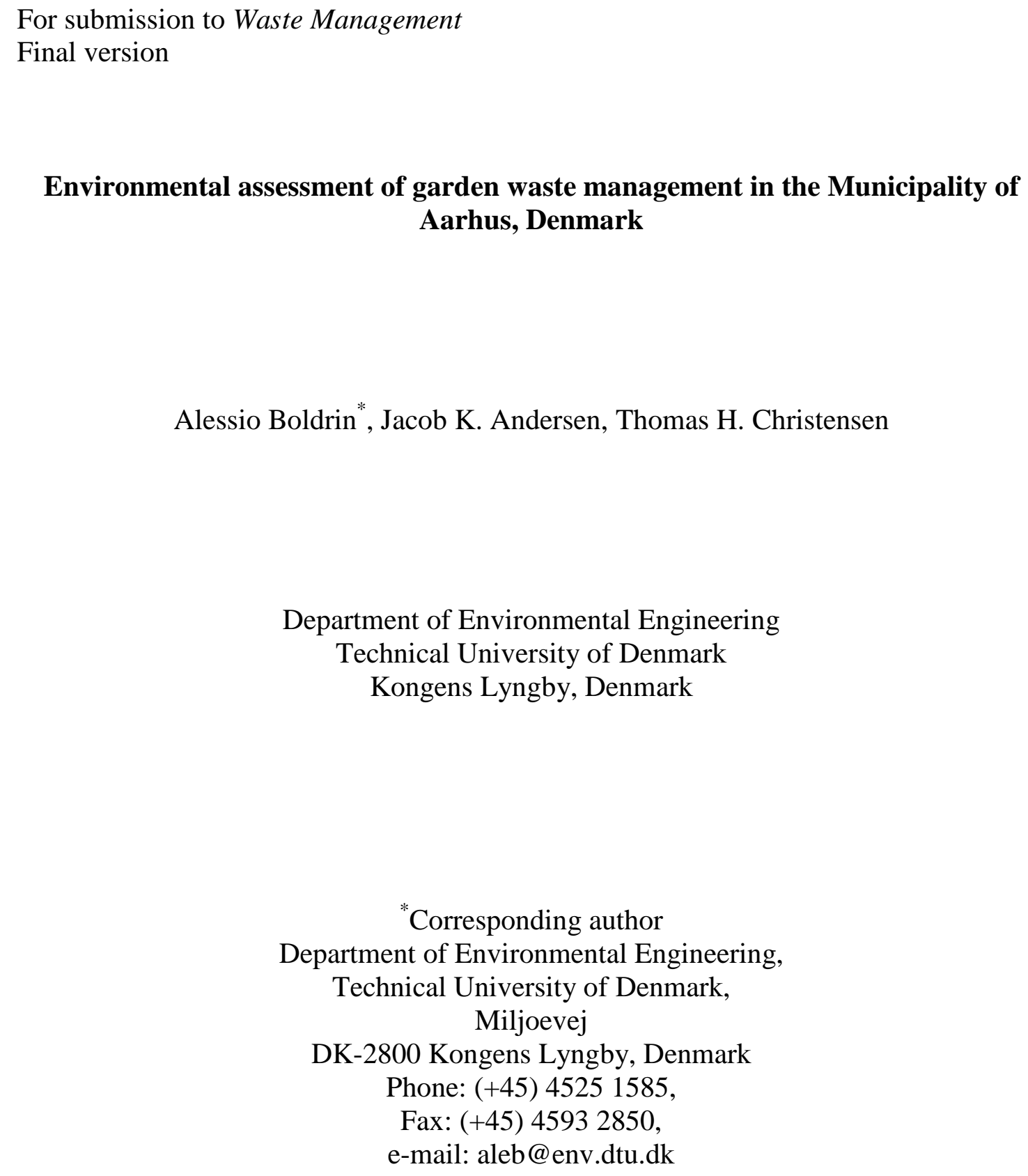
Aarhus, Denmark

\section{Environmental assessment of garden waste management in the Municipality of}

Department of Environmental Engineering Technical University of Denmark Kongens Lyngby, Denmark

${ }^{*}$ Corresponding author Department of Environmental Engineering, Technical University of Denmark, Miljoevej

DK-2800 Kongens Lyngby, Denmark

Phone: (+45) 45251585 ,

Fax: (+45) 4593 2850,

e-mail: aleb@env.dtu.dk 


\section{Abstract}

38 An environmental assessment of six scenarios for handling of garden waste in the municipality of Aarhus (Denmark) was performed from a life cycle perspective by means of the LCA-model EASEWASTE. In the first (baseline) scenario, the current

41 garden waste management system based on windrow composting was assessed, while in 42 the other five scenarios alternative solutions including incineration and home composting of fractions of the garden waste were evaluated. The environmental profile

44 (normalised to Person Equivalent, PE) of the current garden waste management in

45 Aarhus is in the order of -6 to $8 \mathrm{mPE} \mathrm{Mg}^{-1} \mathrm{ww}$ for the non-toxic categories and up to $46100 \mathrm{mPE} \mathrm{Mg}{ }^{-1} \mathrm{ww}$ for the toxic categories. The potential impacts on non-toxic 47 categories are much smaller than what is found for other fractions of municipal solid 48 waste. Incineration (up to $35 \%$ of the garden waste) and home composting (up to $18 \%$

49 of the garden waste) seem from an environmental point of view suitable for diverting 50 waste away from the composting facility in order to increase its capacity. In particular 51 the incineration of woody parts of the garden waste improved the environmental profile 52 of the garden waste management significantly.

53

54

55 Keywords: garden waste, composting, integrated waste management, LCA, 56 EASEWASTE. 
59 Abbreviations:

60 C\&D: Constructions \& Demolition

61 CHP: Combined Heat and Power

62 GHG: Greenhouse Gases

63 GWP: Global Warming Potential

64 LCA: Life Cycle Assessment

65 LCI: Life Cycle Inventory

66 LHV: Lower Heating Value

67 MFA: Material Flow Analysis

68 PAH: Polycyclic Aromatic Hydrocarbons

69 PE: Person Equivalent

70 RS: Recycling Station

71 SFA: Substance Flow Analysis

72 SNCR: Selective Non-Catalytic Reduction

73 VOC: Volatile Organic Compounds

74 VS: Volatile Solids

75 TS: Total Solids

76 U-O-D: Upstream-Operation-Downstream

77 WTE: Waste-To-Energy

78 ww: wet waste 


\section{Introduction}

81 Garden waste is a mixture of organic (e.g. grass clippings, flowers, branches, wood) and inorganic (e.g. soil) materials generated during maintenance of private gardens and public parks (Boldrin \& Christensen, 2010). The amount of garden waste generated has

84 been steadily increasing in Denmark in the last decade. The generation of garden waste 85 was $67 \mathrm{~kg}$ person ${ }^{-1}$ year $^{-1}$ in 1994, while $143 \mathrm{~kg}$ person $^{-1}$ year $^{-1}$ were produced in 2006 86 (Boldrin \& Christensen, 2010), representing more than 18\% of municipal waste generation in 2006 (Miljøstyrelsen, 2010). The increasing generation of garden waste is a major contributor to the increasing generation of residential waste in Denmark (Skovgaard et al., 2005). Capacity of plants treating garden waste is thus high on the agenda of many municipalities.

Collected garden waste is almost exclusively treated by central composting in Denmark (Miljøstyrelsen, 2010). Often only big roots and tree trunks are combusted (<2\%). However, garden waste was recently partly re-classified in Denmark and is

94 currently regulated by the Biomass Ordinance, meaning that branches, wood and roots 95 from garden and park waste can be combusted for energy production without being taxed (Miljøministeriet, 2010). This may potentially make it attractive to recover a woody fraction from the garden waste to be used as a biomass fuel in waste-to-energy (WTE) incineration plants for start up operations. However, not all the garden waste is useful as a fuel, and implementation of home- composting could also be considered an option in finding solutions for the treatment of the increasing amounts of garden waste. Environmental assessment studies comparing alternatives for garden waste management are almost non-existing in literature. Systematic environmental evaluations

103 are thus needed to support rational decision-making processes at the local level 104 concerning garden waste. LCA (Life Cycle Assessment) is a fairly exhaustive tool for 
105 collecting and evaluating data about the generation, collection and treatment of waste.

106 LCA has been used in several studies for assessing waste management both at the

107 system level (e.g. Kirkeby et al., 2006a; Zhao et al., 2009) and at the technology level

108 (e.g. Manfredi \& Christensen, 2008; Damgaard et al., 2009).

109 The goal of the present study is to provide an environmental evaluation of a range of

110 waste management options for dealing with garden waste generated in the Municipality

111 of Aarhus (Denmark). The Municipality of Aarhus has about 300,000 inhabitants is

112 facing a severe capacity problem of the current garden waste composting plant, which

113 only receives about half the garden waste generated in the municipality. The goal is

114 achieved by assessing the environmental profile of:

115 - The current garden waste management having a minimum of wood and reject

116 recovery for combustion (about 6\% of the garden waste)

117 - Potential increases in the amount of wood and reject recovered for combustion (up

118 to $35 \%)$

119 - Potential increases in the amount of wood and reject recovered for combustion (up

120 to 35\%) in combination with increased home composting of garden waste (about

$121 \quad 18 \%)$

122

\section{2. Materials and methods}

124 Garden waste treatment can be considered as a service system, working in respect of the

125 legislation and the environment. The primary service is thus the treatment of a given

126 quantity of garden waste. As suggested by Bjarnadottir et al. (2002), the functional unit

127 of this study was thus defined as: "Handling and treatment of $16,220 \mathrm{Mg}$ of garden

128 waste produced in Aarhus municipality and treated at the Aarhus garden waste 129 composting plant in 2007”. The time horizon of the assessment is 100 years. Eventual 
130 allocations were done on a weight basis. The "zero burdens" assumption was made,

131 since garden waste does not imply any production phase.

132 System boundaries were defined according to the cradle-to-grave principle, thus

133 including all stages and treatments in the life cycle of garden waste. Furthermore,

134 system boundaries were expanded to include benefits/burdens from disposal or purchase

135 of products/services directly linked to waste treatment activities (ash, energy, compost,

136 etc.) (Bjarnadottir et al., 2002). We did not include the environmental loads of the

137 capital goods (construction and demolition of waste treatment facilities and equipment),

138 the treatment and disposal of any solid outputs from the waste-to-energy plant

139 receiving wood and rejects (i.e. bottom ash, fly ash, APC residues, gypsum), and any

140 wastewater generated in different facilities. These aspects were excluded because they

141 were considered of minor importance and for the sake of keeping the comparison of the

142 many scenarios as simple as possible.

143 Only direct consequences (environmental burdens) of the analysed scenarios

144 were accounted for. If, for example, a scenario assesses the diversion of some waste

145 from a current plant, the consequences of available capacity (e.g. other types of waste

146 could be potentially treated) in a specific facility were not evaluated. The report aimed

147 to address future strategies to be implemented when increasing waste generation

148 exceeds the treatment capacity available in current facilities and new installations

149 potentially need to be built.

150 The MFA (Material Flow Analysis)-model STAN was used for setting up the mass flows and the substance flows of the various scenarios (Cencic and Rechberger, 2008). STAN was also used to estimate Volatile Solids (VS) degradation and Total

153 Solids (TS) transfer coefficients used in technology modules involved on the LCA154 modelling. 
156 Kirkeby et al. (2006b). EASEWASTE allows the user to assess the environmental

157 performance of a scenario and to compare different management systems and

158 technologies. The model includes a standard package of datasets, but specific databases

159 for garden waste were entered for this study. Descriptions of specific modules used in

160 the present assessment are available in the literature: biotreatment (Boldrin et al., 161 2010a), incineration (Riber et al., 2008) and use-on-land of treated organic waste 162 (Hansen et al., 2006).

163 The Life Cycle Impact Assessment (LCIA) was performed based on the EDIP97

164 methodology (Wenzel et al., 1997). Results are presented as normalised impact 165 potentials calculated according to normalization factors reported in Table 1 (Stranddorf 166 et al., 2005), where 1 person equivalent (PE) represents the potential impact of an 167 average person for one year including all aspects of life (housing, food, transport, etc.).

168 Emissions of biogenic $\mathrm{CO}_{2}$ are reported in the emission inventory, but accounted as 169 neutral to global warming $(\mathrm{GWP}=0)$ during the characterisation phase of the LCA, as 170 suggested by Christensen et al. (2009).

172 TABLE 1 - Normalisation references for environmental impact categories in EDIP1997.

\section{3. Scenarios description}

175 As shown in Figure 1, the compositing facility in the Municipality of Aarhus received 176 and treated in 2007 16,220 tons of garden waste originating from public collection of 177 private garden waste (2\%), from private households delivered to collection stations 178 (recycling stations, RSs) (64\%), and from public areas and parks (34\%). The 
179 composition of the garden waste is described in Boldrin \& Christensen (2010) and the 180 material fractions are shown in Figure 1.

181 Six different scenarios for handling and treatment of garden waste in Aarhus 182 municipality were compared. The scenarios are here briefly described. System 183 boundaries for Scenarios 1 and Scenario 5 (including diversion of waste at the source) 184 are presented in Figure 1 and Figure 2. System boundaries for the remaining scenarios 185 are specified in Boldrin et al. (2009). An overview of waste routing for the analysed 186 scenarios is provided in Table 2. For all scenarios it is estimated that the amount and 187 treatment of hard materials and foreign items is the same (described later). In all 188 scenarios foreign items, hard materials and wood is removed prior to the actual 189 composting process.

- Scenario 1 - Current management. After the initial sorting, all the collected garden 191 waste is composted $(15,540 \mathrm{Mg})$. The screen residue $>25 \mathrm{~mm}$ are sent to 192 incineration (597 Mg), the residues with size between $8 \mathrm{~mm}$ and $25 \mathrm{~mm}$ are re193 entered in the compost process (recirculated) as structure material. This fraction is 194 estimated to be approximately $1,300 \mathrm{Mg}$, or about $10 \%$. Large items of wood 195 screened out during shredding operations and sent to incineration amounts to 501 196 Mg.

197 - Scenario 2 - Composting and incineration of rejects. After the initial sorting, all the 198 collected garden waste is composted (15,540 Mg), but the screen residues $>8 \mathrm{~mm}$ 199 (1,749 Mg) are in this scenario sent to incineration in Aarhus WTE plant (in 200 Scenario 1 screen residues were recirculated).

201 - Scenario 3 - Composting and seasonal incineration of waste. All garden waste 202 received during the winter months (December, January, and February) is incinerated 203 - only hard materials are removed. Boldrin \& Christensen (2010) showed that 
204 during winter the soil content of the garden waste was low and the calorific value

205 high. The rest of the year garden waste is managed as usual: large wood items are 206 sorted out during shredding and sent to incineration, screen residues $>25 \mathrm{~mm}$ are 207 sent to incineration, screen residues between 8 and $25 \mathrm{~mm}$ are recirculated. The 208 amount of material composted is $11,410 \mathrm{Mg}, 4,631 \mathrm{Mg}$ are sent to incineration 209 (winter waste + large wood items), $935 \mathrm{Mg}$ are recirculated, and reject $>25 \mathrm{~mm}$ 210 amounts to $440 \mathrm{Mg}$.

211 - Scenario 4 - Maximum incineration of garden waste. Garden waste received in 212 winter period, screen residues $>8 \mathrm{~mm}$ and large items of wood are incinerated 213 (5,907 $\mathrm{Mg}$ including 1,276 $\mathrm{Mg}$ of screen residues $>8 \mathrm{~mm})$. Remaining waste is 214 composted (11,410 Mg). No recirculation is assumed in this scenario.

215 - Scenario 5 - Home composting. A part of the generated garden waste is treated in 216 private gardens (home composting). It is assumed that $25 \%$ of the "small stuff" 217 fraction (small branches, leaves, grass, soil etc.) will be composted in private 218 gardens (3,039 Mg) - i.e. the total mass of waste undergoing central composting is 219 decreased by 19\%. This implies reduced transportation of waste (both to recycling 220 stations (RSs) by citizens and between RSs and the composting facility). Large 221 items of wood (502 Mg) and screen residues >25 mm (604 Mg) are incinerated.

222 - Scenario 6 - Home composting and maximum incineration. $25 \%$ of the "small 223 stuff” fraction is composted in private gardens (3,039 $\mathrm{Mg})$ and transportation is 224 reduced. Garden waste received in winter period, screen residues $>8 \mathrm{~mm}$ and large 225 items of wood are incinerated (5,052 Mg, of which 1,035 Mg are screen residues). 226 The remaining waste is composted (9,233 Mg).

228 TABLE 2 - Routing of primary and secondary waste flows for the analysed scenarios. 
FIGURE 1 - LCA system boundaries for scenario 1.

FIGURE 2 - LCA system boundaries for scenario 5.

\section{Inventory and modelling of relevant data}

233 The following sections describe how the collected data are modelled in the assessment.

234 Loads and savings are described as "direct", when they originate directly from the operation of the garden waste treatment facilities, and "indirect" when they, although associated with garden waste management, take place outside the actual treatment facility. The indirect aspects are further distinguished in upstream (e.g. provision of energy to the treatments facilities) or downstream (e.g. substitution of inorganic fertilizers by compost) contributions. An overview of different aspects included in the assessment is summarized in Table 3 according to the Upstream-Operation-Downstream (U-O-D) concept (Gentil et al., 2009).

TABLE 3 - Overview of different aspects considered in the assessment.

\subsection{Collection and transportation distances}

In the Municipality of Aarhus, citizens deliver garden waste by car to six recycling stations (RSs). The average distance between households and the RSs is $4.5 \mathrm{~km}$ and it was estimated from a user survey that was carried out at one of the RSs (Lystrupvej). Including a return trip (delivery of garden waste is in many cases not combined with other activities), the average driven distance is thus $2 * 4.5 \mathrm{~km}$ (9 km in total). The gasoline consumption for waste delivery (collection) is hence estimated to be $8.9 \mathrm{l} \mathrm{Mg}^{-1}$ of wet waste (ww) (Andersen et al., 2010a).

The average transportation distance between the RSs and the composting plant was calculated considering the amount of waste (number of loads) delivered from each 
255 RS in 2007. The weighted average distance from RS to Aarhus composting plant is 12.7

$256 \mathrm{~km}$ - i.e. the total transportation distance is $2 * 12.7 \mathrm{~km}(25.4 \mathrm{~km})$. The diesel

257 consumption for covering such distance is estimated to be $0.06 \mathrm{l} \mathrm{km}^{-1} \mathrm{Mg}^{-1}$ 258 (EASEWASTE, 2008).

259 Both the WTE plant and the Construction \& Demolition (C\&D) waste recycling 260 centre are located next to the composting plant, so these transportation distances are 261 assumed to be negligible.

262

263

\subsection{Garden waste composition}

264 Monthly generation, material fraction composition and chemical characterization of 265 garden waste is thoroughly reported in Boldrin \& Christensen (2010). A representative 266 sampling and mass reduction method - described in Boldrin et al. (2009) - was used for seasonal characterization (8 samples during one year, twice per season) of garden waste and its classification into five material fractions (i.e. small stuff, branches, wood, hard materials, foreign objects).

As described in Andersen et al. (2010a), foreign items (e.g. plastic bags), hard materials (e.g. stones, rocks, bricks) and large items of wood are removed prior to or during the shredding operations. Foreign items are sent to incineration, hard materials are recycled in a C\&D waste facility and the wood is sent to incineration after being

274 dried together with roots. In total 16,220 Mg of garden waste were treated at Aarhus composting plant in 2007 (15,540 Mg of shredded waste $+500 \mathrm{Mg}$ of wood to incineration $+78 \mathrm{Mg}$ of hard materials $+106 \mathrm{Mg}$ of foreign items to incineration). 
279 Composting of garden waste in Aarhus composting plant is performed in outdoor 280 windrows. The process lasts typically 55-60 weeks. The piles have a trapezoidal cross 281 section ( $4.5 \mathrm{~m}$ high, $9 \mathrm{~m}$ wide in the bottom and $1 \mathrm{~m}$ wide at the top) and are turned 282 infrequently, approximately every 6-8 weeks. Gaseous emissions produced during the 283 decomposition of waste are not controlled nor treated.

In the modelling, a diesel consumption of 3.04 litre $\mathrm{Mg}^{-1}$ ww and an electricity consumption of $0.2 \mathrm{kWh} \mathrm{Mg}^{-1}$ ww were considered (details available in Andersen et al., 2010a); in both cases, inventories of upstream processes were taken from the EDIP database. Gaseous emissions included in the assessment are reported in Table 4, according to Andersen et al. (2010b). A detailed description of the data collection process and all available data for Aarhus composting plant are collected in Andersen et al. (2010a). Such inventory comprises all energy and material consumptions at the facility, mass balances for the process (including estimation of transfer coefficients and VS degradation values), measured emissions (mainly gaseous) to the environment, and characterization and use of the outputs.

In normal operations, at the end of the composting process the material is processed in a trommel screen with $8 \mathrm{~mm}$ and $25 \mathrm{~mm}$ sieves. The material with particle size $>25 \mathrm{~mm}$ (approximately $5 \% \mathrm{ww}$ ) is incinerated in the nearby WTE plant. The

300 material with particle size between 8 and $25 \mathrm{~mm}(\sim 10 \% \mathrm{ww})$ is recirculated and used as structure material when establishing new windrows. The main fraction is compost (particle size $<8 \mathrm{~mm}, \sim 85 \% \mathrm{ww}$ ), which is transported back to the RSs and sold to citizens - either as compost or mixed with sandy soil. According to a user's survey 
304 (Andersen et al., 2010c), compost is mainly used in private gardens partly substituting 305 for peat-based growth media and commercial N, -P, -K fertilizers.

The substitution of commercial fertilizers is modelled according to the nutrient contents in compost and their utilization rate (Hansen et al., 2006). The complete

308 chemical-physical characterization of compost produced in Aarhus composting plant is

309 reported in Andersen et al. (2010a). Utilization rates are assumed to be $30 \%$ for $\mathrm{N}$ and $310100 \%$ for P and K (Hansen et al., 2006). Hence, the amount of substituted mineral 311 fertilizers per $\mathrm{Mg}$ of compost is: $1.64 \mathrm{~kg} \mathrm{~N}, 1.08 \mathrm{~kg} \mathrm{P}$, and $10.8 \mathrm{~kg} \mathrm{~K}$. The study also 312 accounts for carbon still bound in the soil at the end of the 100 years time horizon. This 313 amounts to $14 \%$ of the carbon inputs with compost, according to the modelling done by 314 Bruun et al. (2006) for Danish conditions. Bound carbon is credited to the system as 315 avoided $\mathrm{CO}_{2}$ emissions.

From an LCA perspective, the use of compost in replacement of peat is modelled on a 1:1 volume basis (Boldrin et al., 2010b). Thus, assuming that the average

318 densities of peat and compost in the Danish context are $200 \mathrm{~kg} / \mathrm{m}^{3}$ and $760 \mathrm{~kg} / \mathrm{m}^{3}$ 319 respectively (Boldrin et al., 2010b), $1 \mathrm{Mg}$ of compost substitutes $263 \mathrm{~kg}$ peat. All the benefits and burdens of substituting peat with compost have been accounted for in EASEWASTE according to Boldrin et al. (2010b). The substituted peat-profile includes the four phases of peat life cycle: peatland preparation, extraction, transportation, and use. The two materials (compost and peat) are compared taking into account the 324 different chemical compositions and the different leaching characteristics. Carbon 325 emitted as $\mathrm{CO}_{2}$ from degradation of peat - during 100-years time frame of the assessment - is considered a greenhouse gas (Boldrin et al., 2010b).

The actual use of compost by private citizens was reported by Andersen et al., 2010c) based on interviews with compost users. Less than $50 \%$ of the citizens using 
compost in their garden were replacing peat or mineral fertilizers with compost. In an

330 LCA context, this means that the benefits from peat replacement are in reality smaller

331 than what is potentially possible if the compost is used in rational way. A 50\%

332 substation is modelled in EASEWASTE by assuming that $1 \mathrm{Mg}$ of compost substitutes

$333131.5 \mathrm{~kg}$ peat (instead of $263 \mathrm{~kg}$ ) and that only 50\% of the N,P,K nutrients contained in

334 compost replace mineral fertilizers.

335

336

\subsection{Modelling of the thermal treatment}

Thermal treatment of waste is performed in the Aarhus WTE plant. The facility is equipped with a furnace with a Combined Heat and Power (CHP) energy recovery system. Cleaning of flue gas is done with a semidry (2 lines) and wet (1 line) systems.

340 Activated carbon is used for removal of Dioxin and $\mathrm{Hg}$. $\mathrm{NO}_{\mathrm{x}}$ is removed by SNCR. The annual capacity is $240,000 \mathrm{Mg}$. The input of materials and energy to the process is included. Details can be found in EASEWASTE (2008). The treatments of wastewater, bottom ash, fly ash and sludge are not included in the assessment. The efficiency of the plant is $20.7 \%$ for electricity production and $74 \%$ for heat production, calculated on the Lower Heating Value (LHV) of the feedstock. Coal-based electricity and coal-based heat are the marginal technologies for the energy produced in Aarhus WtE plant (Riber et al., 2008; Fruergaard et al., 2010).

\subsection{Modelling of hard materials recycling}

350 The flow of materials sent to the C\&D recycling is rather small (see later). In the modelling it is assumed that the hard material is undergoing crushing. The use of the resulting material (similar to gravel) is modelled to offset extraction of gravel and crushed rock. The LCI dataset for such process is included in EASEWASTE (2008). 
354 The modelling of this part of the system is considered uncertain, but, as seen later, it has very little influence on the results.

356

\subsection{Modelling of home composting}

358 Home composting is supposed to be performed in private backyards. For the LCA359 modelling it is assumed that:

- $\quad$ No impurities are entered in the composters;

- There is only one solid output (compost);

- $\quad$ The degradation of VS in the waste is $40 \%$;

363 Because of lack of data, eventual leaching from the composters is not modelled.

364 Therefore, the only direct emissions from the process are in gaseous form (to 365 atmosphere). The magnitude of air emissions is reported in Table 4.

\section{Results}

368 In this section, results of the assessment are presented and the analysed scenarios are compared. Due to lack of space, disaggregated LCA results are presented only for Scenario 1. Similar results can be found in Boldrin et al. (2009) for the remaining scenarios.

Figure 3 presents results for potential non-toxic impacts from the current management of garden waste in Aarhus (Scenario 1). The composting facility is the main potential source of environmental impacts (positive PE values). Contributions to Global Warming come from greenhouse gases (GHGs) generated from combustion of 376 fuel (fossil $\mathrm{CO}_{2}$ ) in heavy machineries (for example front loaders, excavators, shredder, 377 etc.) or during the composting process $\left(\mathrm{CH}_{4}\right.$ and $\left.\mathrm{N}_{2} \mathrm{O}\right)$. Significant contributions arise also during collection (emissions of fossil $\mathrm{CO}_{2}$ ) of garden waste because of the high fuel 
consumption per Mg of waste in private cars. Potential impacts on Photochemical

380 Ozone Formation also originate mainly from the composting process, collection and transportation, because of Volatile Organic Compounds (VOC), $\mathrm{NO}_{\mathrm{x}}$ and CO emissions during fuel combustion in engines.

The composting process is the main contributor to Nutrient Enrichment

384 (eutrophication). $\mathrm{NO}_{\mathrm{x}}$ are emitted to air from fuel combustion during the use of heavy machineries and ammonia $\left(\mathrm{NH}_{3}\right)$ evaporates from composting windrows. $\mathrm{NO}_{\mathrm{x}}$ and $\mathrm{NH}_{3}$ (together with $\mathrm{SO}_{2}$ from engines) are also the main contributors to Acidification. The use of compost in gardens results in some credits in Acidification due to savings in use of peat. Replacement of mineral P fertilizer production by the use of compost results in important savings in Nutrient Enrichment category (almost counterbalancing detrimental impacts) as large discharges of $\mathrm{P}$ to freshwater are avoided. compost in substitution of peat, especially in terms of Global Warming (peat is considered as fossil carbon, see section 4.3). The credit is mainly due to avoided use of energy for extraction and production of peat.

The incineration of wood and foreign items also contributes with credits to the system together with the stones that are routed to the C\&D facility. The credits are due to the electricity and heat produced by the WTE plant, offsetting the production of coalbased energy elsewhere in the energy system. The credits exceed the loads to Global

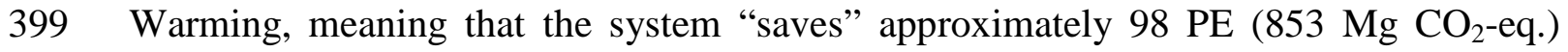
with respect to global warming. All other non-toxic categories show net (loads) impacts. 401 
Figure 4 shows the potential toxic environmental impacts from the current management of garden waste. The main potential impacts in Ecotoxicity in Water originate from fossil fuel burning during collection, transportation and composting. The main contributors to Ecotoxicity in Water are PAH, which are released when fossil fuel

408 is combusted, and strontium, which is emitted during the production of gasoline

409 (upstream process). Use of compost in gardens is the most important process in the 410 toxic categories. It has large contributions to Human Toxicity via Soil and Human 411 Toxicity via Water, mainly due to chromium and arsenic contained in the compost 412 materials. Smaller contributions originate also from mercury, lead and zinc contained in 413 compost.

FIGURE 4 - Potential toxic environmental impact from the current management.

Figure 5 and Figure 6 compare potential impacts arising from the six analysed scenarios. For each of the impact categories, potential impacts originating from the different processes have been aggregated into a single normalised indicator. The base scenario (scenario 1) is the least environmentally favourable of all scenarios regarding non-toxic categories. The introduction of both more incineration and home composting could have potential improvements in all non-toxic impact categories.

424 FIGURE 5 - Comparison of potential non-toxic environmental impacts for analyzed 425 scenarios. 
means of private cars, but they are small. The small contribution by home composting is due to the small amount of garden waste being home-composted. Space availability in backyards, size of the materials (large wood items may be too big for backyard composters) and people's attitudes influence the actual amounts diverted. Another second issue concerns the quality (e.g. maturation) and use (e.g. gardening) of compost which could be very variable in case of home-composting and thus difficult to model.

Figure 6 - Comparison of potential toxic environmental impacts for analyzed scenarios.

Incineration of a larger fraction of the collected garden waste results in significant improvements in most of the impact categories. The additional waste incinerated results in potential savings in Global Warming from avoided production of electricity and heat from fossil fuels (coal). Photochemical Ozone Formation is improved with the introduction of incineration because of a reduction in VOC emissions

443 from heavy machineries used in the composting plant. On the other side, increased 444 incineration produces larger emissions of $\mathrm{NO}_{\mathrm{x}}$, resulting in a worse environmental profile in Acidification and Nutrient Enrichment.

It is worth noting that the amount of garden waste that could be optimally diverted to incineration is limited. For technical reasons, the ash content and the lower 448 heating value (LHV) restrict what can be incinerated (Boldrin \& Christensen, 2010):

449 - The woody fraction and partly the fraction containing branches (may need sieving);

- All garden waste collected during winter (may need sieving).

451 In absolute terms, toxic categories show relatively high potential impacts on human 452 toxicity (via water and via soil) for all the scenarios. The dominant factor is the content 453 of heavy metals in compost. The LCA methodology estimates the potential toxic effects 
454 based on the amount of heavy metals, without taking into account effective 455 concentrations. As presented in Andersen et al. (2010a), the compost produced in 456 Aarhus composting plant respects legal and quality standards regarding potential 457 pollutants (it is actually suitable for organic farming), meaning that compost can be used 458 on land without any significant risks. Seen from another perspective, most of the heavy 459 metals contained in compost were originally contained in the soil fraction (Boldrin \& 460 Christensen, 2010) and therefore do not contribute to an increase of the background 461 concentration of heavy metals in the soil when the compost is spread on land. Therefore, 462 less emphasis should be put on the results for the toxic categories and it may be needed 463 in the future to develop another approach for characterization of the impact of heavy 464 metals in soils (Christensen et al., 2007).

465

466

5.1. Sensitivity and uncertainty analysis

467 A number of uncertain/assumed parameters were screened. Their uncertainty level was 468 qualitative assessed:

- The substitution rate between compost and peat is considered highly uncertain 470 because it is based on a precautionary assumption extrapolated from the user survey.

471 - The $\mathrm{CH}_{4}$ emission during composting is based on precise and repeated 472 measurements, supported with a mass balance. The uncertainty is low.

473 - Nitrogen losses during composting (determining $\mathrm{N}_{2} \mathrm{O}$ and $\mathrm{NH}_{3}$ emissions) are 474 uncertain: the $\mathrm{NH}_{3}$ measurements were inaccurate and the $\mathrm{N}$ balance was imprecise.

475 - Distance driven by means of private cars for delivery of garden waste to the 476 recycling stations was considered having medium level of uncertainty. 
- The assumption regarding the type of energy which is substituted by the energy produced in the WTE plant is considered rather robust. The assumption is supported by studies done on the Danish energy systems.

A sensitivity test was performed to determine the influence of different parameters on the results. The quantitative results of the sensitivity test are presented graphically in Figure 7 and Figure 8, where variation intervals show the consequences of the changes presented in Table 5.

\section{TABLE 5 - Sensitivity test for different parameters and scenarios.}

FIGURE 7 - Results of the sensitivity test for non-toxic impact categories.

FIGURE 8 - Results of the sensitivity test for toxic impact categories.

Critical parameters were determined combining information on their relevance on the final result (according to the LCA results), the uncertainty evaluation and the sensitivity analysis. According to Table 6, the most critical parameters were peat substitution and the $\mathrm{N}$ degradation rate.

TABLE 6 - Results of the sensitivity and uncertainty analysis.

\section{Discussion and recommendations}

The current garden waste management system in Aarhus is finely organised and has good environmental performances. Emissions and impacts rising from the current garden waste treatment in Aarhus are quite small, in the order of few mPE per Mg of waste treated. The environmental burdens of the current management are in the range -6 to $8 \mathrm{mPE} / \mathrm{Mg}$ of ww for the non-toxic categories and up to $100 \mathrm{mPE} / \mathrm{Mg}$ of ww for the 
toxic categories. The potential impacts for non-toxic categories are much smaller than what found for other types of municipal solid waste (e.g. Kirkeby et al., 2006a). substitution of commercial growth media potentially has important benefits for the environment: actually utilization of compost represents in most cases the major credit to the system. However, the actual substitution obtained by private use of compost in gardens may be much less that the potential and it is critical in the future to obtain better data on this aspects and maybe also educate the compost users so the benefits of using compost are optimized.

The comparison of the six analysed scenarios did not show clear and large

512 differences in their environmental profile, so that a clear conclusion on the most 513 preferable solution could not be drawn. However, potential improvements in the current

514 as well as in alternative managements were defined. Emissions of GHG during the 515 composting process are the major contribution to global warming from the current 516 garden waste management. These emissions could potentially be limited with more 517 frequent turnings of the windrows and/or by establishing windrows of smaller size.

518 Incineration of some garden waste showed potential environmental benefits.

519 Anyway, it must be ensured that garden waste with specific characteristics (e.g. high 520 LHV and low ash content) is selected for the thermal treatment. The study showed that

521 if waste can be sorted out, then woody fractions can be incinerated with large benefits.

522 If it is considered to incinerate mixed garden waste, then the suitable waste is that being 523 received during the winter season (sieving may be needed). Increasing the share of 524 screen residues (recirculate) sent for energy recovery was also found to be potentially 525 beneficial. However, this would reduce the amount of structure material available for 526 the composting process. 
528 the avoided collection), but no major improvements were found under the analysed

529 conditions. Also in this case, if home composting is being implemented, a good practice

530 for both process management and use of compost on soil should be ensured to obtain

531 the environmental benefits and reduce the environmental loads.

532

533

\section{Conclusion}

534 An environmental assessment of six scenarios for handling of garden waste in the municipality of Aarhus (Denmark) was performed from a life cycle perspective by means of the LCA-model EASEWASTE. In the first (basic) scenario, the current garden waste management was assessed, while in the other five scenarios alternative solutions including incineration and home composting of waste were evaluated.

The current garden waste management in Aarhus has good environmental

540 performances: impacts rising from waste treatment are in the order of a few mPE per

$541 \mathrm{Mg}$ of waste treated for non-toxic impact categories, which is several orders of 542 magnitude smaller than what is found for other fractions of municipal solid waste. The 543 environmental burdens of the current management are in the range -6 to $8 \mathrm{mPE} \mathrm{Mg}^{-1}$ 544 ww for the non-toxic categories and up to $100 \mathrm{mPE} \mathrm{Mg}^{-1} \mathrm{ww}$ for the toxic categories.

545 The study showed that some of the garden waste (may be up to 50\%) can 546 potentially be diverted to alternative handling options. Incineration and home 547 composting seem suitable for such purpose, as long as the diverted waste has proper 548 characteristics. 
551 Affaldscenter Aarhus, 2008. Grønt regnskab 2007: Affaldscenter Aarhus, øvrige anlæg. Aarhus Kommune, Natur og Miljø.

553

554 Andersen, J.K., Boldrin, A., Christensen, T.H., Scheutz, C., 2010a. Mass balances and 555 life-cycle inventory for a garden waste windrow composting plant (Aarhus, Denmark). 556 Waste Management \& Research, doi:10.1177/0734242X09360216.

557

558 Andersen, J.K., Boldrin, A., Samuelsson, J., Christensen, T.H., Scheutz, C., 2010 b.

559 Quantification of greenhouse gas emissions from windrow composting of garden waste.

560 Journal of Environmental Quality 39, 713-724.

561

562

Andersen, J.K., Christensen, T.H., Scheutz, C., 2010c. Substitution of peat, fertiliser 563 and manure by compost in hobby gardening: User surveys and case studies. Waste Management, doi:10.1016/j.wasman.2010.07.011

565

566 Bjarnadottir, H.J., Fridriksson, G.B., Johnsen, T., Sletnes, H., 2002. Guidelines for the

567 Use of LCA in the Waste Management Sector. Nordtest Report TR 517. Nordtest, 568 Espoo, Finland.

569

570 Boldrin, A., Andersen, J.K., Christensen, T.H., 2009. Miljøvurdering af haveaffald i

571 Aarhus Kommune. (LCA report: Environmental assessment of garden waste

572 management in Aarhus Kommune, in Danish). Department of Environmental

573 Engineering, Technical University of Denmark, Kgs. Lyngby, Denmark. Last accessed

574 September 2010 at: <http://www.aarhuskommune.dk/ /media/Subsites/AffaldVarme- 
575 Aarhus/Om-AffaldVarme-Aarhus/Bibliotek/Rapporter/Aarhus-haveaffald-engelsk-

576 rapport.ashx>

577

578 Boldrin, A., Christensen, T.H., 2010. Seasonal generation and composition of garden 579 waste in Aarhus (Denmark). Waste Management 30, 551-557.

580

581

Boldrin, A., Hansen, T.L., Damgaard, A., Bhander, G.S., Møller, J., Christensen, T.H., 582

2010a. Modelling of environmental impacts from biological treatment of organic 583 municipal waste (EASEWASTE). Waste Management (revised version submitted).

584

585

Boldrin, A., Hartling, K.R., Laugen, M., Christensen, T.H., 2010b. Environmental 586 inventory modelling of the use of compost and peat in growth media preparation. Resources, Conservation and Recycling 54, 1250-1260.

588

Bruun, S., Hansen, T.L., Christensen, T.H., Magid, J., Jensen, L.S., 2006. Application of processed organic municipal solid waste on agricultural land: a scenario analysis. Environmental Modeling and Assessment 11, 251-265.

592

593 Christensen, T.H., Gentil, E., Boldrin, A., Larsen, A.W., Weidema, B.P., Hauschild, 594 M.Z., 2009. C balance, carbon dioxide emissions and global warming potentials in 595 LCA-modelling of waste management systems. Waste Management \& Research 27, $596 \quad 707-715$.

597

598 Christensen, T.H., Bhander, G.S., Lindvall, H.K., Larsen, A.W., Fruergaard, T.H., 599 Damgaard, A., Manfredi, S., Boldrin, A., Riber, C., Hauschild, M.Z., 2007. Experience 
600 with the use of LCA-modelling (EASEWASTE) in waste management. Waste

601 Management \& Research 25, 257-262.

602

603 Damgaard, A., Riber, C., Fruergaard, T., Hulgaard, T., Christensen, T.H., 2009. Life604 cycle-assessment of the historical development of air pollution control and energy 605 recovery in waste incineration. Waste Management 30, 1244-1250.

606

607 EASEWASTE (2008). Database of EASEWASTE 2008, Version 4:5:001. Department 608 of Environmental Engineering, Technical University of Denmark, Kgs. Lyngby, 609 Denmark.

610

611 Fruergaard, T., Christensen, T.H., Astrup, T., 2010. Energy recovery from waste

612 incineration: Assessing the importance of district heating networks, Waste Management $613 \quad 30,1264-1272$.

614

615 Gentil, E., Aoustin, E., Christensen, T.H., 2009. Greenhouse gas accounting and waste 616 management. Waste Management \& Research, 27, 696-706.

617

618 Hansen, T.L., Bhander, G.S., Christensen, T.H., Bruun, S., Jensen, L.S., 2006. Life 619 cycle modelling of environmental impacts from application of processed organic 620 municipal solid waste on agricultural land (EASEWASTE). Waste Management \& 621 Research 24, 153-166.

622

623 Kirkeby, J.T., Bhander, G.S., Birgisdóttir, H., Hansen, T.L., Hauschild, M.Z., 624 Christensen, T.H., 2006a. Evaluation of environmental impacts from municipal solid 
625 waste management in the Municipality of Aarhus. Waste Management \& Research 24, 626 16-26.

627

628 Kirkeby, J.T., Hansen, T.L., Birgisdóttir, H., Bhander, G.S., Hauschild, M.Z., 629 Christensen, T.H., 2006b. Environmental assessment of solid waste systems and 630 technologies: EASEWASTE. Waste Management \& Research 24, 3-15.

631

632 Manfredi, S., Christensen, T.H., 2009. Environmental assessment of solid waste 633 landfilling technologies by means of LCA-modeling. Waste Management 29, 32-43.

634

635 Miljøministeriet, 2010. Bekendtgørelse om ændring af bekendtgørelse om

636 biomasseaffald (Tilføjelse vedrørende grene, stød og rødder fra have-park-affald),

637 Miljøministeriet, den 11. januar 2010. (Ordinance amending the Ordinance on biomass

638 waste) in Danish.

$639<\underline{\text { http://www.mst.dk/Virksomhed_og_myndighed/Affald/Nyheder+affald/nyhed_biomas }}$

640 se.htm $>$ (accessed august 2010).

641

642 Miljøstyrelsen, 2010. Affaldstatistik 2007 og 2008. Orientering fra Miljøstyrelsen Nr. 5

6432010 (Waste statistics 2007 and 2008. Data generated by the Danish EPA) in Danish.

$644<$ http://www2.mst.dk/udgiv/publikationer/2010/978-87-92668-21-9/pdf/978-87-92668-

645 22-6.pdf $>$ (accessed August 2010)

646

647 Riber, C., Bhander, G.S., Christensen, T.H., 2008. Environmental assessment of waste 648 incineration in a life-cycle-perspective (EASEWASTE). Waste Management and 649 Research 26, 96-103. 
651 Skovgaard, M., Moll, S., Moller Andersen, F., Larsen, H., 2005. Outlook for Waste and 652 Material Flows. Baseline and Alternative Scenarios. ETC/RWM Working Paper

653 2005/1. European Topic Centre on Resource and Waste Management. <http://

654 scp.eionet.europa.eu/announcements/ann1113909495> (accessed August 2010).

655

656 Stranddorf, H.K., Hoffmann, L., Schmidt, A., 2005. Impact categories, normalisation 657 and weighting in LCA, Updated on selected EDIP97-data. Environmental News No. 78 658 2005. Danish Environmental Protection Agency, Danish Ministry of the Environment, 659 Copenhagen, Denmark.

660

661 Zhao, Y., Wang, H-T, Lu, W-J, Damgaard, A., Christensen, T.H., 2009. Life-cycle 662 assessment of the municipal solid waste management system in Hangzhou, China 663 (EASEWASTE). Waste Management and Research 27, 399-406.

664 


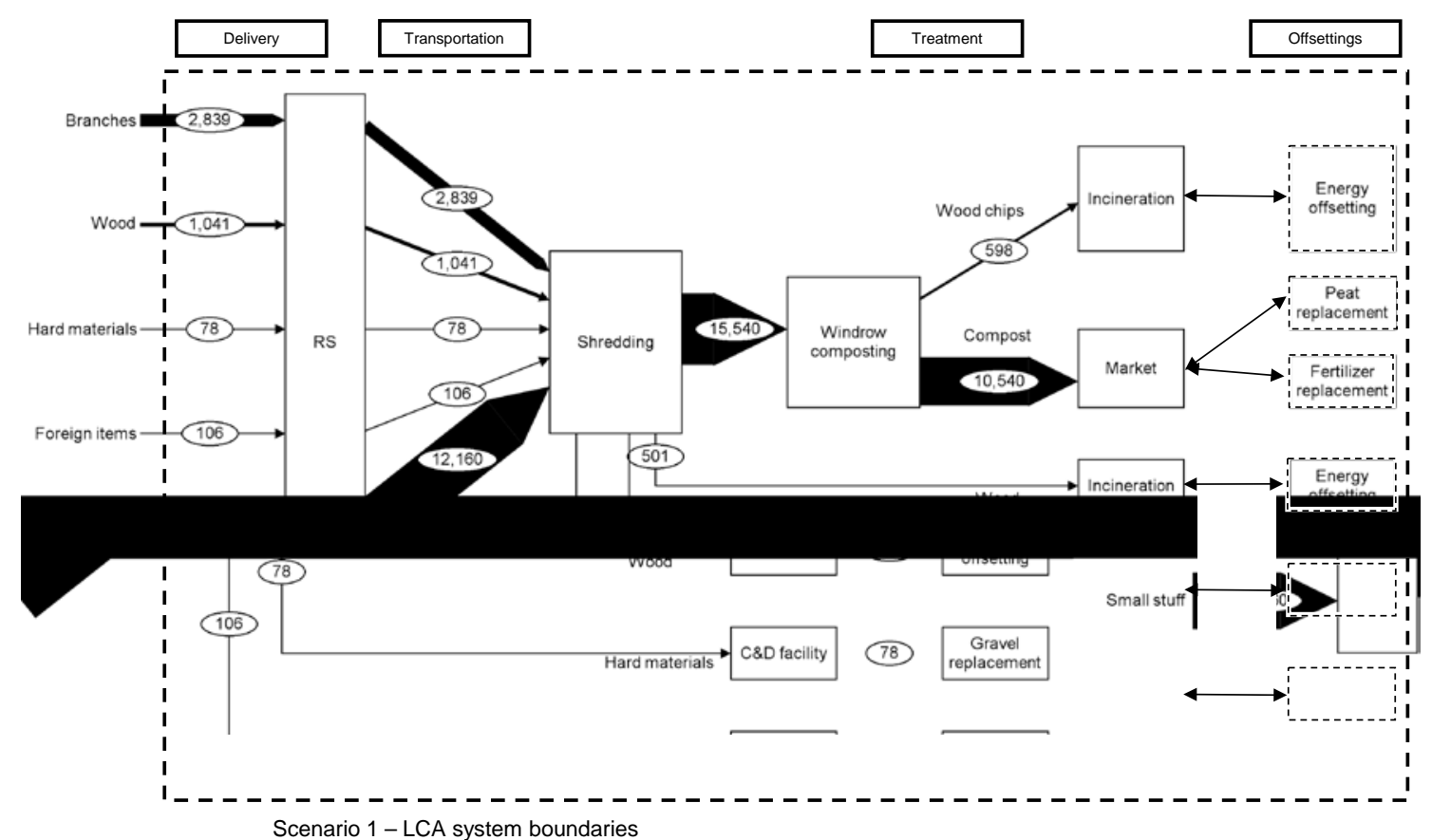

665 Scenario $1-$ LCA system boundaries

666 Figure 1 - LCA system boundaries for scenario 1 - Current management of garden 667 668 669 670 671 672 673 674 675 
676

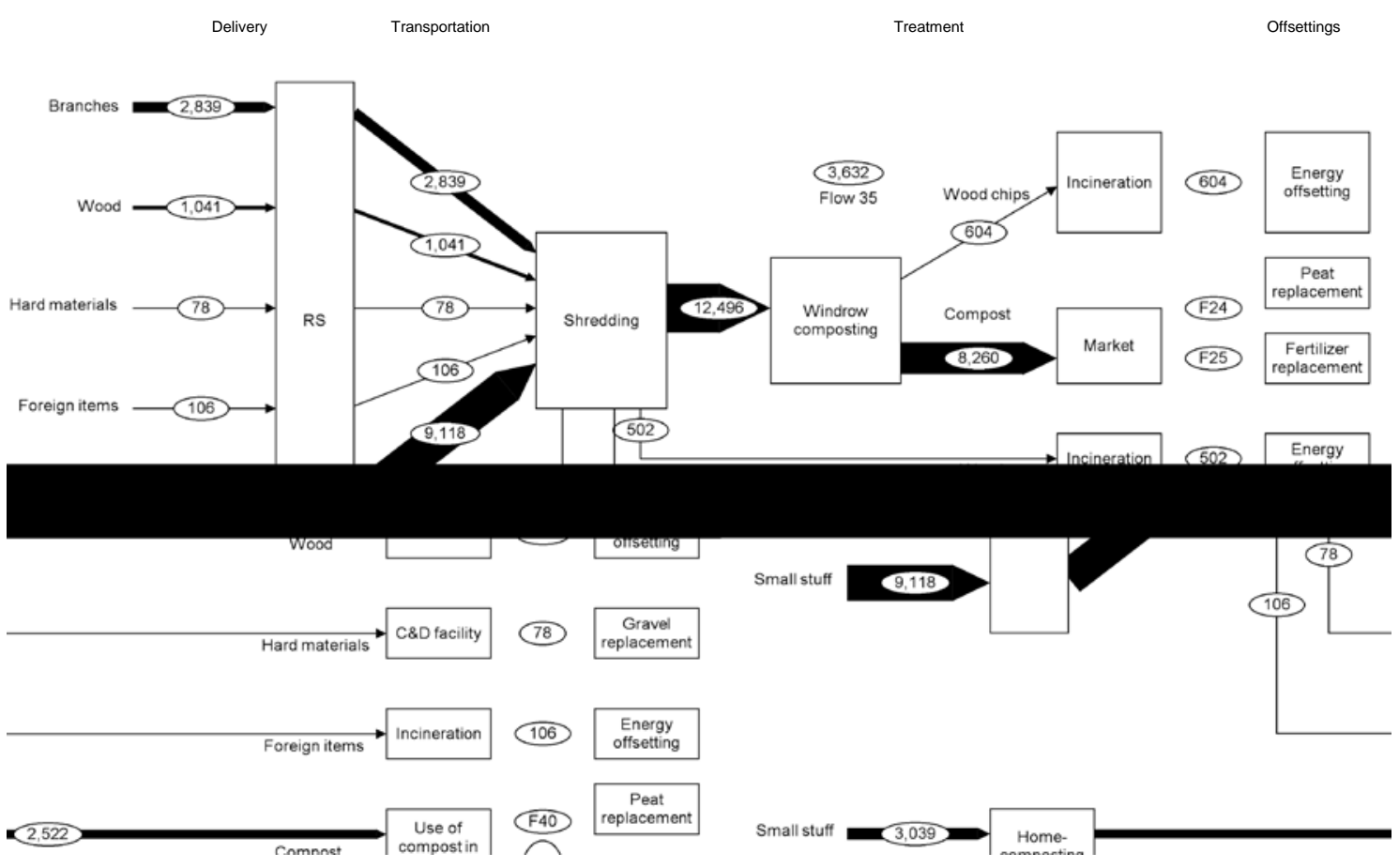

Scenario 5 - LCA system boundaries

678 Figure 2 - LCA system boundaries for scenario 5 - Home composting. Material flows

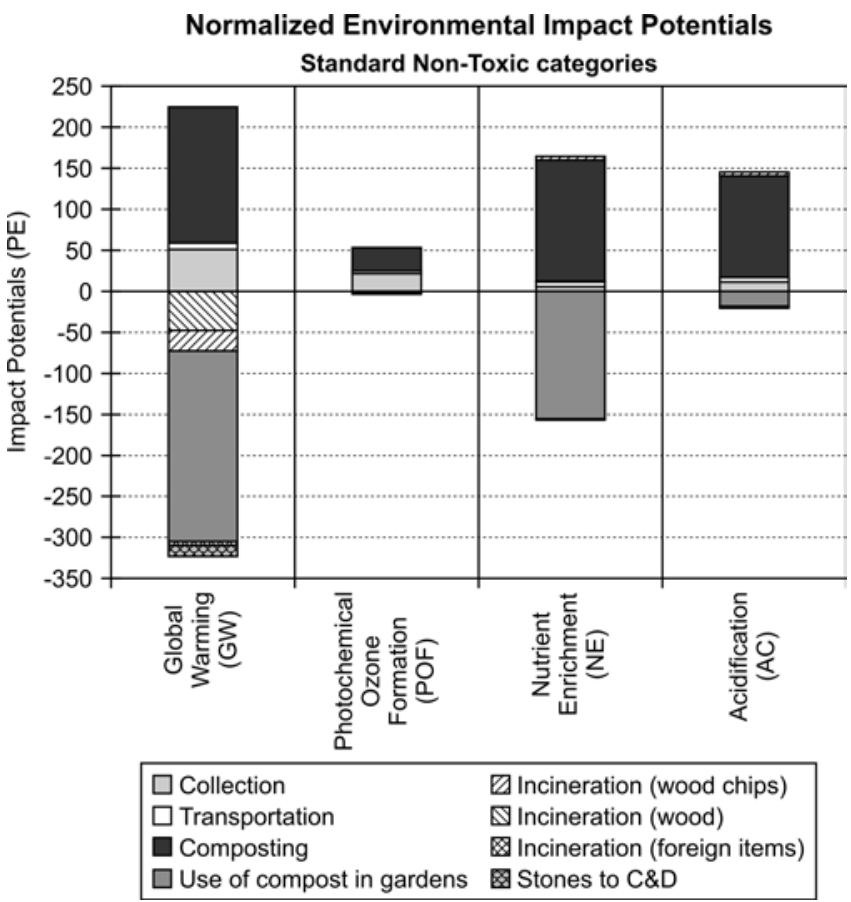

Figure 3 - Potential non-toxic environmental impacts from the current management of 683 garden waste $(16,220 \mathrm{Mg})$. 


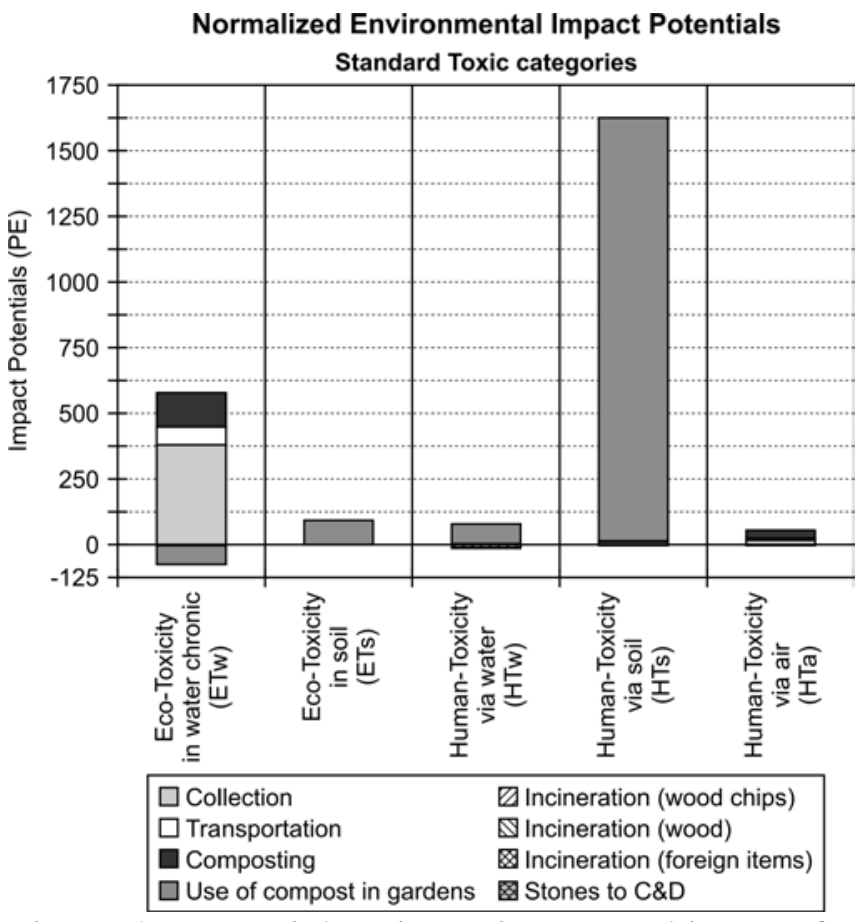

689

Figure 4 - Potential toxic environmental impact from the current management of garden

691 waste $(16,220 \mathrm{Mg})$.

692

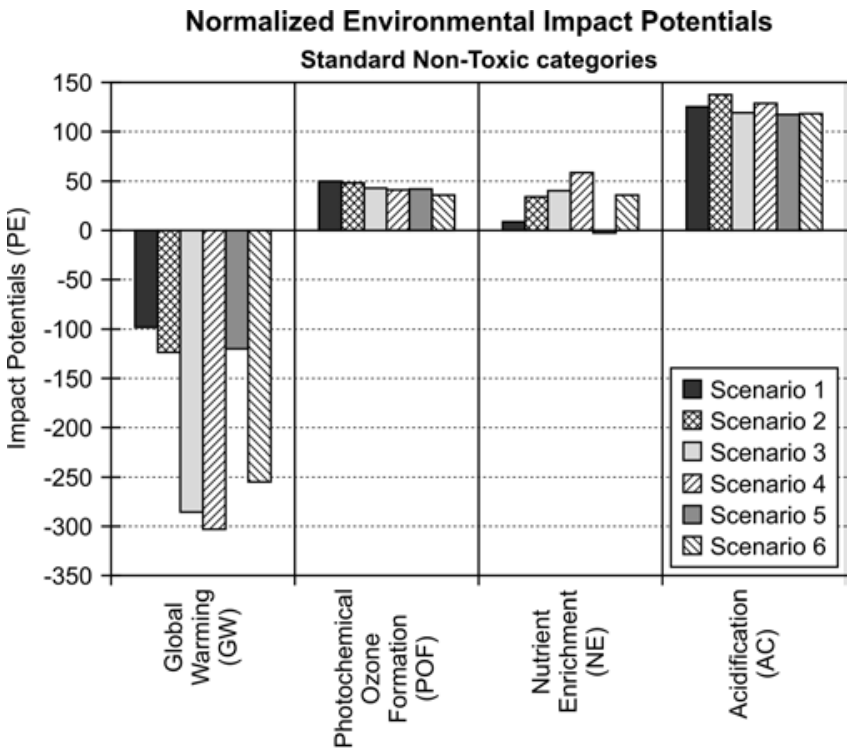

Figure 5 - Comparison of potential non-toxic environmental impacts for analysed scenarios $(16,220 \mathrm{Mg}$ of garden waste). 


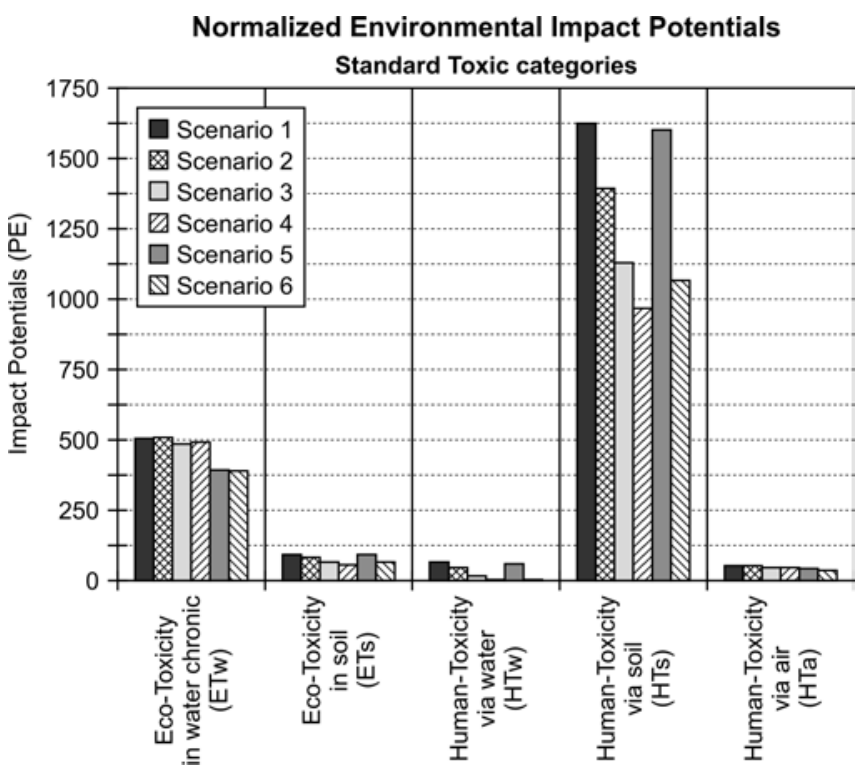

705

Figure 6 - Comparison of potential toxic environmental impacts for analysed scenarios 707

708 $(16,220 \mathrm{Mg}$ of garden waste).

709

710

711

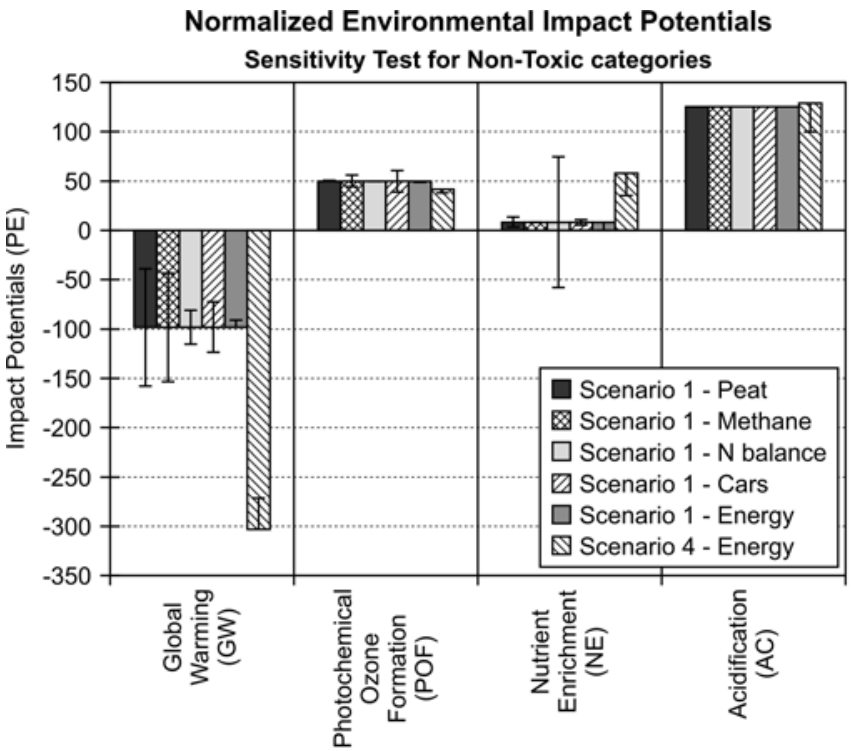

Figure 7 - Results of the sensitivity test for non-toxic impact categories. 


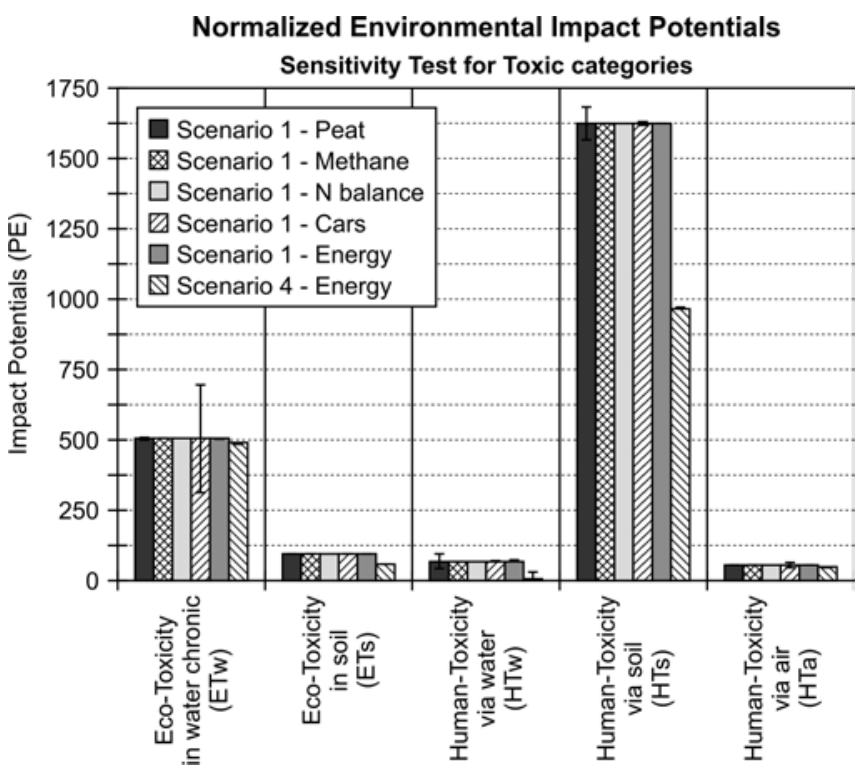

720

Figure 8 - Results of the sensitivity test for toxic impact categories.

721 
722 Table 1 - Normalisation references for environmental impact categories in EDIP1997

723 (Stranddorf et al., 2005)

\begin{tabular}{|l|l|l|l|}
\hline Impact category & $\begin{array}{l}\text { Geographical } \\
\text { scale }\end{array}$ & Characterisation unit & $\begin{array}{l}\text { Normalization } \\
\text { reference } \\
\text { [Characterisation } \\
\text { unit/person/year }]\end{array}$ \\
\hline Non-toxic impacts & \multicolumn{3}{l|}{} \\
\hline Global warming (GW) & Global & $\mathrm{kg} \mathrm{CO}_{2}$-equivalents & $8.7 \cdot 10^{3}$ \\
\hline Acidification (AC) & Regional & $\mathrm{kg} \mathrm{SO}_{2}$-equivalents & $7.4 \cdot 10^{1}$ \\
\hline Nutrient enrichment (NE) & Regional & $\mathrm{kg} \mathrm{NO}_{3}$-equivalents & $1.19 \cdot 10^{2}$ \\
\hline Photochemical ozone formation (POF) & Regional & $\mathrm{kg} \mathrm{C}_{2} \mathrm{H}_{4}$-equivalents & $2.5 \cdot 10^{1}$ \\
\hline Toxic impacts & \multicolumn{3}{l}{} \\
\hline Human toxicity via air & Local & $\mathrm{m}^{3}$ air & $6.09 \cdot 10^{10}$ \\
\hline Human toxicity via water & Regional & $\mathrm{m}^{3}$ water & $5.22 \cdot 10^{4}$ \\
\hline Human toxicity via soil & Regional & $\mathrm{m}^{3}$ soil & $1.27 \cdot 10^{2}$ \\
\hline Ecotoxicity via water & Regional & $\mathrm{m}^{3}$ water & $3.52 \cdot 10^{5}$ \\
\hline Ecotoxicity via soil & Regional & $\mathrm{m}^{3}$ soil & $9.64 \cdot 10^{5}$ \\
\hline
\end{tabular}


Table 2 - Routing of primary and secondary waste flows for the analysed scenarios.

\begin{tabular}{|c|c|c|c|}
\hline Scenario & Treatment & Amount (Mg) & Fraction diverted \\
\hline 1 & $\begin{array}{l}\text { Central composting } \\
\text { WTE (wood) } \\
\text { WTE (rejects) } \\
\text { Home composting }\end{array}$ & $\begin{array}{c}15,540 \\
501 \\
597 \\
-\end{array}$ & \\
\hline 2 & $\begin{array}{l}\text { Central composting } \\
\text { WTE (wood) } \\
\text { WTE (rejects) } \\
\text { Home composting. }\end{array}$ & $\begin{array}{c}15,540 \\
501 \\
1,749 \\
-\end{array}$ & Recirculate $(>8 \mathrm{~mm})$ \\
\hline 3 & $\begin{array}{l}\text { Central composting } \\
\text { WTE (wood) } \\
\text { WTE (rejects) } \\
\text { Home composting. }\end{array}$ & $\begin{array}{c}11,410 \\
4,631 \\
440 \\
-\end{array}$ & Winter waste \\
\hline 4 & $\begin{array}{l}\text { Central composting } \\
\text { WTE (wood) } \\
\text { WTE (rejects) } \\
\text { Home composting }\end{array}$ & $\begin{array}{c}11,410 \\
4,631 \\
1,276 \\
-\end{array}$ & $\begin{array}{l}\text { Winter waste } \\
\text { Recirculate }(>8 \mathrm{~mm})\end{array}$ \\
\hline 5 & $\begin{array}{l}\text { Central composting } \\
\text { WTE (wood) } \\
\text { WTE (rejects) } \\
\text { Home composting }\end{array}$ & $\begin{array}{c}12,500 \\
502 \\
604 \\
3,039 \\
\end{array}$ & $25 \%$ small stuff \\
\hline 6 & $\begin{array}{l}\text { Central composting } \\
\text { WTE (wood) } \\
\text { WTE (rejects) } \\
\text { Home composting }\end{array}$ & $\begin{array}{l}9,233 \\
4,017 \\
1,035 \\
3,039\end{array}$ & $\begin{array}{l}\text { Winter waste } \\
\text { Recirculate (>8mm) } \\
25 \% \text { small stuff }\end{array}$ \\
\hline
\end{tabular}


Table 3 - Overview of different aspects considered in the assessment.




Table 4 - Estimated values for gaseous emissions from the composting process.

\begin{tabular}{|c|c|c|}
\hline & Central composting & Home composting \\
\hline Methane $\left(\mathrm{CH}_{4}\right)$ & $2.7 \%$ of degraded $\mathrm{C} *$ & $3 \%$ of degraded $\mathrm{C} * *$ \\
\hline Nitrous oxide $\left(\mathrm{N}_{2} \mathrm{O}\right)$ & $1.2 \%$ of total $\mathrm{N} *$ & $1.05 \%$ of total $\mathrm{N} * *$ \\
\hline Ammonia $\left(\mathrm{NH}_{3}\right)$ & $6.6 \%$ of total $\mathrm{N} * *$ & $6.3 \%$ of total $\mathrm{N}^{* *}$ \\
\hline Carbon monoxide (CO) & $0.34 \%$ of degraded C * & $0.04 \%$ of total C ** \\
\hline
\end{tabular}


Table 5 - Sensitivity test for different parameters and scenarios.

\begin{tabular}{|c|c|c|c|c|c|c|}
\hline Test name & Tested scenario & Parameter changed & Change & From & \multicolumn{2}{|c|}{ To (+/-) } \\
\hline Scenario 1 - peat & Scenario 1 & Peat substitution & $\pm 40 \%( \pm 20 \%)$ & 131.5 kg (50\%) & 79 kg (30 \%) & 184 kg (70 \%) \\
\hline Scenario 1 - methane & Scenario 1 & $\mathrm{CH}_{4}-\mathrm{C}$ emissions & $\pm 50 \%$ & $2.24 \%$ & $1.12 \%$ & $3.36 \%$ \\
\hline Scenario $1-\mathrm{N}$ balance & Scenario 1 & $\mathrm{~N}$ degradation & $\pm 50 \%$ & $8 \%$ & $4 \%$ & $12 \%$ \\
\hline Scenario 1 - cars & Scenario 1 & Gasoline consumption & $\pm 50 \%$ & $8.9 \mathrm{l} / \mathrm{km}$ & $13.4 \mathrm{l} / \mathrm{km}$ & $4.4 \mathrm{l} / \mathrm{km}$ \\
\hline Scenario 1 - energy & Scenario 1 & Marginal electricity mix & & Coal & \multirow{2}{*}{\multicolumn{2}{|c|}{ Av. Danish mix }} \\
\hline Scenario 4 - energy & Scenario 4 & & & & & \\
\hline
\end{tabular}


Table 6 - Results of the sensitivity and uncertainty analysis.

\begin{tabular}{|l|l|l|l|}
\hline $\begin{array}{l}\text { Parameter } \\
\text { changed }\end{array}$ & $\begin{array}{l}\text { Relevance on the } \\
\text { LCA results }\end{array}$ & Uncertainty & Sensitivity \\
\hline Peat substitution & Large & Large & $\begin{array}{l}\text { GW: medium } \\
\text { NE, HT: large }\end{array}$ \\
\hline $\mathbf{C H}_{\mathbf{4}}$ emissions & Medium & Small & GW: medium \\
\hline N degradation & Medium & Large & AC, NE: large \\
\hline $\begin{array}{l}\text { Gasoline } \\
\text { consumption }\end{array}$ & Small & Medium & $\begin{array}{l}\text { GW,AC,HT: medium } \\
\text { POF,ET: large }\end{array}$ \\
\hline $\begin{array}{l}\text { Marginal } \\
\text { electricity mix }\end{array}$ & Large & Small & $\begin{array}{l}\text { AC,NE: medium } \\
\text { HT: large }\end{array}$ \\
\hline
\end{tabular}

